\title{
Credit Risk Management of Commercial Banks
}

\author{
Ping $\operatorname{Han}^{1}$ \\ ${ }^{1}$ School of Economics and Finance, Shandong Jiaotong University, Jinan, Shandong, China \\ Correspondence: Ping Han, School of Economics and Finance, Shandong Jiaotong University, Jinan, Shandong, \\ China. E-mail: vhanping@126.com
}

Received: January 4, 2015

Accepted: January 23, 2015

Online Published: January 26, 2015

doi:10.5430/jbar.v4n1p8

URL: http://dx.doi.org/10.5430/jbar.v4n1p8

\begin{abstract}
Credit risk has always been the main risk of the banking industry and the financial industry also is the main object and the core content of financial institutions and regulatory departments to prevent and control. With the continuous development of international financial market, domestic commercial banks will be under the impact of international and domestic factors more, take more internal and external risk. Therefore, research on prevention of commercial banks credit risk has theoretical and practical value. This paper explores the sources of credit risk in Chinese commercial banks, analyzes Chinese commercial banks credit management experience and their insufficiency, and puts forward some countermeasures to control the credit risk of commercial banks in China under the new situation.
\end{abstract}

Keywords: Commercial banks, Credit management, Risk analysis

\section{Credit risk of commercial banks}

\subsection{Credit risk of commercial banks}

Credit risk refers to the possible losses of banks coming from borrowers' failing to repay. Credit risk mainly exists in three common forms: principal loss risk; interest loss risk and profit loss risk. In recent years, China's commercial banks had made a large amount of theoretical and practical exploration to strengthen credit risk management in order to prevent the credit risk. However, asset quality of commercial banks is still not so good.

In real life, people are more concerned about the possibility of loss in credit assets. Therefore, this article discusses narrow meaning of credit risk, which is the possibility of credit assets loss in the future. Specifically, the credit risk is the impact on commercial banks coming from changes in various factors, which will probably lead to decrease of credit asset value even overall bank assets decline.

\subsection{Classifications of credit risk}

Commercial banks' credit activities are influenced not only by the macro economic situation but also by the industry adjustments and other external factors. They are also influenced by internal operations. Therefore, the risks are some potential events which may be expected or not, coming from loans that may lead to losses of commercial banks' credit assets. With the development of financial market and the expansion of banks' business, credit risk is not only refers to the risk of loan assets, but also refers to guarantee, acceptance and discount, letters of credit and other credit business. According to different events that may cause the loss in credit assets, the credit assets risks are generally divided into the following types:

(1) operating risk

According to the definition of the Basel committee, the operational risk refers to the risk of loss resulting from inadequate or problems of internal processes, people and systems or from external events.

According to the causes of risks, operating risk can be subdivided into two types: one is operation failure or failure risk, including personnel risk, process risk and technology risk. another is the operation strategy risk, which is the risk caused from inappropriate strategy in facing external events, such as political, regulatory, tax, government, society, market competition. The former is mainly related to internal control efficiency or quality management, also known as the internal risk while the latter is mainly related to the external events, also called external events or external related risk.

In recent years, China's financial market increasingly opening up, domestic commercial banks are facing more and more competitions. It requires commercial banks strengthen their risk management. But, local commercial banks 
have a lot of operational risks caused by the lack of property rights, bad inner control and the process improper design of operation.

(2) market risk

Market risk is probably losses coming from unfavorable changes of interest rate, exchange rate and credit assets price. It can be divided into interest rate risk, exchange rate risk and inflation risk. At present, many commercial banks develop a new credit product- floating interest rate loan to avoid exchange rate risk. They also avoid exchange rate risk by currency swaps and forward contract. But, inflation risk may still decrease banks' assets which lead to losses of principals and interests.

(3) moral hazard

The moral hazard may take place after contracts signing between principals and agents. Due to information asymmetry, information owners may destroy benefits of others by conducting some actions in order to maximize their own utilities. This will result in losses of other people. There are many types of principal-agent relationships during commercial banks management process. Therefore, in the course of commercial banks, moral hazard caused by information asymmetry is inevitably. Because the main profits source of Chinese commercial banks is still credit business, moral hazard problem has become the focus of risk prevention in recent years.

\section{Present situations of credit risk management in Chinese commercial banks}

In China, Researches of commercial banks' credit risk management have just started at the end of the 80's. Credit risk is the most important financial risk encountered by Chinese commercial banks. Due to a long period of planned economy, banks are lack of risk consciousness. They have ignored the credit risk management for a very long period. In the practice of banking management, the risk management in China has experienced three stages: control of risk losses under planned economy, risk management under planned commodity economy and commercial banks risk management at present.

\subsection{Traditional credit risk management under the planned economy}

In the 30 years before 1978, under the traditional planned economy, loans are controlled by government. Banks are lack of risk concept, credit risk management focus mainly on corruption, embezzlement and other behaviors breaking financial disciplines. Loans are allocated according to government instructions. Banks adhere to principles of "plan, material guarantee, return" to strengthen credit management and control credit risks.

\subsection{Credit risk management under the planned commodity economy}

In October 1984, Chinese government clearly put forward that China is a planned commodity economy on the basis of public ownership. Credit business developed quickly after that. Credit risk began to gradually exposed and intensified. Because of this, China established the system of deposit reserves, bad debt reserves, excess reserves and asset liability ratio system. Mechanism of credit risk management is established initially. But the loans in this period are mostly provided to state-owned enterprises without any guarantee, together with the serious intervention of local government, many enterprises defaulted bank loans, which eventually led to a large number of bad loans. According to researches, in the 1980 's, $20 \%$ of loans provided by state-owned banks are defaulted.

\subsection{Credit risk management under the system of socialist economy}

At present, Chinese commercial banks began to pay attention to the customer's credit evaluation. But, as to measurement and management, they are behind the time. Their methods are basically limited to traditional qualitative analysis. The risk management level in domestic banks is mostly at a primary stage of non systematic management. Chinese banks are relatively weak in measurement of credit risk and built up of a comprehensive risk management system. Credit risk management cannot meet the need of rapid changed market economy. Through the development of credit risk management, banks will come to a new stage systematic risk management. Based on this, banks can make improvement and perfection on the management system and gradually get to the third stage strategic portfolio management. But, it is not likely that Chinese commercial banks will introduce and adopt developed countries' credit risk measurement models. That is because in china, enterprise credit rating and change information database has not established. The lack of credit rating and change data increases difficulty of measuring credit risk. 


\section{Problems in Chinese Credit risk management}

\subsection{Unreasonable credit organizational structure}

Chinese commercial banks have not formed a completely top-down system of credit management. During the process of implementing credit policy, credit power of sub-branch banks is too large. Sometimes, they cannot execute credit policy of their higher authorities well. They may extend credit for short-term gains and finally lead to increase of credit risk. Synchronically, commercial banks are lack of communication. This kind of information asymmetry contributed to cheating from enterprises and individuals and increased difficulties to prevent and control credit risks. In commercial banks, credit management department and credit business department are not independent, this weakened the effective monitoring of credit management department on the business sector.

\subsection{The government influence commercial banks}

In the early days of the planned economy and the opening up, banks are used as economic regulator by the government. The main tasks of banks are helping government to achieve control on economy. Banks have not completely independent. With the deepening of reform, the government intervention in commercial banks credit behavior decreased, but the intervention still exists in some areas. In addition, with the local government's unceasing expansion of financing, the debt comes from local government infrastructure and public utilities are securitized. Commercial banks are facing more and more credit risks. This should be focused on by commercial banks in recent years.

\subsection{Credit structure is irrational which caused high credit risk}

In recent years, Chinese commercial banks mainly provided loans to large and medium-sized state-owned enterprises or to those companies who have government background, as well as the speedily developed and profitable industries such as real estates, iron and steels and automobiles. Small and medium-sized enterprises, private enterprises and rural area companies are hard to get loans. Loans are concentrated in those specific areas, which made credit structure unreasonable and easy to be influenced by policy, economic cycle, industry life cycle and other factors. Once the risks outbreak, commercial banks will encounter great losses. In addition, the concentrated credit structure will definitely destroy economic structure and its long-term healthy development.

\subsection{Imperfect credit management and supervision}

Commercial banks in China are lack of unified rating system when they provide loans to borrowers. Still, they haven't a mature risk warning mechanism. The warning system in Chinese commercial banks is lack of rigorous qualitative, quantitative analysis which made it unable to objectively reflect the borrowers' financial situations. Meanwhile, relationship lending still exists in many banks. This increased credit risks of commercial banks. After loans are released, commercial banks cannot properly assess the usage and repayment of them. This will lead to a lot of bad loans, increasing the credit risks of commercial banks. In addition, commercial banks also have unreasonable asset liability ratios, imperfect regulation laws and unequal allocation of credit rights.

\section{Countermeasures to strengthen credit risk management}

\section{1 improve credit risk management; perfect the post responsibility and accountability system}

The effective implementation of the "three check" system is a key factor to guard against the risks of loans. Commercial banks should introduce policies about the credit archives management and "three check". Implementation details of post loan management approach should be introduced as soon as possible. Each commercial bank should implement the post responsibility. Daily assessment on decision makers should also be established. Commercial banks should combine leadership management with loan management. Special emphasis should be done on the relevant personnel quality and accountability.

\subsection{Perfect credit organizational structure}

Draw lessons from the developed countries, Chinese commercial banks should improve credit organizational structures. First of all, vertical credit management system of head-branch-sub branch should be improved to increase implementation of the credit policies and strengthen the monitoring of the sub branch banks' credit risks. Secondly, lateral information sharing should be strengthened; credit management departments and business departments should be independent. Credit management department should intensify supervision on business department. Commercial banks improve the efficiency of credit risk monitoring in accordance with the scientific principles. Credit risk will be greatly reduced if there is a set of suitable credit system. 


\subsection{Optimize the credit structure; reduce the concentration of credit}

Commercial banks should strengthen the study and judgment of the national economic policy; optimize credit structure according to the country's monetary policy actively and timely. Loans should be provided not only to the state-owned large and medium-sized enterprises, but also to those who have great potential and grow rate. Also, moderate attention should be pay to those small and medium-sized enterprises and national supported industries. In addition, commercial banks should adjust time structure of loans. Reasonable allocate short-term and long-term credit loans, which also helps to reduce the credit risk of commercial banks.

\subsection{Establish a sound credit warning system}

In order to prevent risks, commercial banks must establish a sound credit risk early warning system, quantitative a series of evaluation index. Commercial banks can choose borrowers in accordance with the unified credit rating system guard against and dissolve the credit risk from the source head. In addition, the commercial banks should strengthen the post-loan monitoring. After the issuance of bank loans, commercial banks should regularly check the borrowers' financial statements and management on a regular basis.

\subsection{The establishment of risk transformation and the compensation mechanism of credit assets}

When there are evidence of risks, commercial banks should take timely measures to recover, claim for recovery from borrowers and guarantees. At the same time, commercial banks should improve and optimize loan structure, allocation and guarantees, manage the loans according to relevant laws, and transfer risk effectively. To beware of the risks, commercial banks should draw adequate reserves according to related regulatory rules.

\section{References}

Barth J.R, Brumbaugh R.D. Sauethaft D. (1989). Thrift Institution Failures: Estimating the Regulator's Closure Rule. Research in Financial Services, JAI 1989, (1).

Eisenbeis R.A. (1977). Pitfalls Application of discriminate analysis in business, finance and economics. Journal of Finance, 1977, (32).

Liu Yali. (2010). Credit risk of Chinese commercial banks under the loose monetary policy. The mass of business. 2010 (4).

Li Guanlin. (2011). Research on credit risk management of Commercial banks of China. Harbin University of Commerce.

LIi Zhihui. (2006). The commercial banks management. Chinese Financial Publishing House.

Wei Jlyue. (2010). credit risk of Chinese commercial banks. Study on the problems and Countermeasures of Economic Research Guide. 2010, 07. 